\title{
HYPERSENSITIVITY TO THE POLLEN OF OLEA EUROPEA IN THE MEDITERRANEAN AREA
}

\author{
Nataša SKITARELIĆ and Neven SKITARELIĆ \\ Zadar General Hospital, Zadar, Croatia \\ Received in February 2009 \\ Accepted in February 2009
}

Olive pollen is one of the most important causes of inhalant allergy in the Mediterranean countries $(1,2)$. We investigated the frequency of hypersensitivity to the pollen of Olea europea in pollen allergic patients in Dalmatia, Croatia (3). A total of 810 patients with pollen allergy, were examined: 469 (58\%) male and $341(42 \%)$ female, age range from 4 to 53 years.

The patients were assessed on the basis of medical history, clinical examination, measurement of pulmonary function (adults and children older than 7 years), intradermal prick test, and immuno-enzyme UniCAP test (UniCAP, Fluoroenzymeimmunoassay; Pharmacia, Upjohn, Sweden) for specific IgE antibodies. We used standard allergen prick tests produced by the Institute of Immunology in Zagreb, Croatia.

Our study, like two earlier $(4,5)$, confirmed that grasses, especially Parietaria officinalis, are the main pollen allergens. Trees rarely cause allergies in the Croatian part of the Adriatic coast (4). Hypersensitivity to Olea europea occurred in 66 of $810(8.15 \%)$ assessed patients with pollen allergy. Olea europea and Fraxinus ornus belong to the family of Oleaceae. Both trees are part of the local flora. We confirmed the hypersensitivity to Olea europea allergen and excluded cross-reactivity between these plants by specific IgE antibodies measurements.

The most prevalent clinical manifestations were rhinitis in $39(59 \%)$ of 66 patients allergic to Olea europea pollen and bronchial asthma in $20(30.3 \%)$ patients. It is interesting to note that 51 patients $(77 \%)$ lived in towns and the rest in villages; only 3 patients (4\%) lived on the islands. The prevalence of pollen allergies in patients living in the coastal region is recognised in other Mediterranean countries (6).

The hypersensitivity to Olea europea allergen in our patients was significantly lower than in other Mediterranean countries (Figure 1); $(\mathrm{p}<0.01)$, where varied from $21 \%$ to $31.8 \%(7-10)$. The reason for this difference may be sought in greater industrial pollution $(11,12)$ and greater area cultivated with olives $(13)$ in other Mediterranean countries.

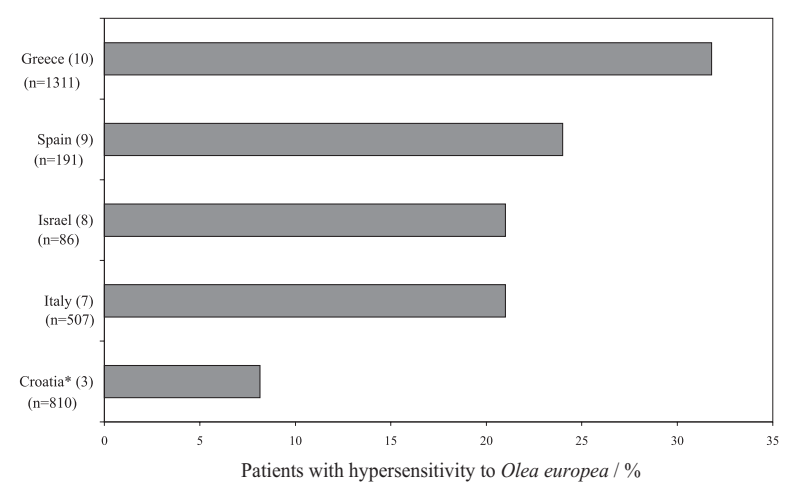

Figure 1 Hypersensitivity to the pollen of Olea europea in five Mediterranean countries, ${ }^{*} p<0.01$. 


\section{REFERENCES}

1. Asturias JA, Arilla MC, Gomez-Bayon N, Martinez J, Martinez A, Palacios R. Clonin and expression of the panallergen profilin and the major allergen (Ole e 1) from olive tree pollen. J Allergy Clin Immunol 1997;100:36572 .

2. Tejera ML, Villalba M, Batanero E, Rodriguez R. Identification, isolation and characterization of Ole e 7, a new allergen of olive tree pollen. J Allergy Clin Immunol 1999;104:797-802.

3. Skitarelić N, Sindik N, Skitarelić N, Mazzi A, Vuletić A, Mišulić J. Učestalost senzibilizacije na maslinu u bolesnika s peludnom alergijom na području Zadra i Dubrovnika [Hypersensitivity to pollen of Olea europea in patients with pollen allergy in the areas of Zadar and Dubrovnik, in Croatian]. Liječ Vjesn 2004;126: 65-70.

4. Sindik N, Restović-Sirotković M, Skitarelić B, Balić J, Kavurić-Hafner K, Peharda-Sabolić V, Čvorišćec B. Polinoze na području Dalmacije, Istre i Hrvatskog primorja s posebnim osvrtom na pelud Parietariae [Pollinosis in the area of the Dalmatian, Istrian and Croatian coast with special emphasis on Parietariae pollen, in Croatian]. Liječ Vjesn 1989;111:263-5.

5. Cvitanović $S$, Marušić M, Juričić M, Vrdoljak E, Petrovečki M, Rozga M, Stavljenić-Rukavina A. Hypersensitivity to Parietaria officinalis pollen in newcomers to the area with the plant. Allergy 1993;48:592-7.
6. Ariano R, Passalacqua G, Panzani R, Scordamaglia A, Venturi S, Zoccali P, Canonica GW. Airborne pollens and prevalence of pollenosis in western Liguria: a 10-year study. J Invest Allergol Clin Immunol 1999;9:229-34.

7. Verini M, Rossi N, Verotti A, Pelaccia G, Nicodemo A, Chiarelli F. Sensitization to environmental antigens in asthmatic children from a central Italian area. Sci Total Environ 2001;270:63-9.

8. Geller-Bernstein C, Lahoz C, Cardaba B, Hassoun G, IancoviciKidon M, Kenett R et. al. Is it "bad hygiene" to inhale pollen in early life? Allergy 2002;57(Suppl. 71):37-40.

9. Ledesma A, Rodriguez R, Villalba M. Olive-pollen profilin. Molecular and immunologic properties. Allergy 1998;53:520-6.

10. Gioulekas D, Papakosta D, Damialis A, Spieksma F, Giouleka P, Patakas D. Allergenic pollen records (15 years) and sensitization in patients with respiratory allergy in Thessaloniki, Greece. Allergy 2004;59:174-84.

11. Zhang XD, Lotvall J, Arakawa H, Welinder H, Skerfving S. Relationship between IgG1 levels and airway responses in guinea pigs actively and passively sensitized to hexahydrophthalic anhydride. Allergy 1998;53:20-7.

12. Salvi S. Pollution and allergic airways disease. Curr Opin Allergy Clin Immunol 2001;1:35-41.

13. Macchia L, Aliani M, Caiaffa MF, Carbonara AM, Gatti E, Iacobelli A, Strada S, Casella G, Tursi A. Monitoring of atmospheric conditions and forecast of olive pollen season. Experientia Suppl 1987;51:95-9.

\section{CORRESPONDING AUTHOR:}

Nataša Skitarelić, MD

Put Murvice 33

23000 Zadar, Croatia

E-mail:neven.skitarelic@zd.t-com.hr 